8. Цимбал С. В. Синергетичний та акмеологічний аспекти формування професійної компетентності студентів / С. В. Цимбал, О. В. Вознюк, С. О. Кубіцький // Нові технології навчання: [наук.-метод. зб.]. - К. : Науково-методичний центр вищої освіти, 2005. - Випуск 40. - 279 с.

Стаття надійшла до редакції 13.05.2012 р.

УДК 377.35

О. П. Крупський, кандидат психол. наук, дочент,

К. С. Кіба,

Дніпропетровський націіональний університет ім. О. Гончара

\title{
ВЗАЕМОЗВ'ЯЗОК МІЖ ЕМОЦІЙНОЮ КОМПЕТЕНТНІСТЮ ТА ЛІДЕРСТВОМ ЯК СКЛАДНИКАМИ ПЕДАГОГІЧНОЇ ДІЯЛЬНОСТІ
}

Крупський О. П., Кіба К. С. Взасмозв'язок між емоційною компетентністю та лідерством як складниками педагогічної діяльності.

Статтю присвячено проблемі взаємозв'язку емоційного інтелекту та лідерства, їх впливу на педагогічну діяльність, а також виявленню залежності між емоційним інтелектом вчителів та учнів середніх і вищих навчальних закладів. лідерства.

Ключові слова: лідерство, мотивачія, емоційний інтелект, компетениї̈, стилі емоційного

Крупский А. П., Киба К. С. Взаимосвязь между эмоииональной компетентностью и лидерством как составляющими педагогической деятельности.

Статья посвящена проблеме взаимосвязи эмочионального интеллекта и лидерства, их влияния на педагогическую деятельность, а также выявлению связи между эмоциональным интеллектом учителей и учеников средних и высших учебных заведений.

Ключевые слова: лидерство, мотивация, эмочиональный интеллект, компетенции, стили эмочионального лидерства.

Krupsky O., Kiba K. Interrelation between emotional competence and leadership as components of pedagogical activity.

The article is devoted to a problem of interrelation of emotional intelligence and leadership, their influence on pedagogical activity, and also communication identification between emotional intelligence of teachers and pupils of averages and higher educational institutions.

Key words: leadership, motivation, emotional intelligence, competences, styles of emotional leadership.

У сучасних умовах робота педагогічного колективу стає все більш емоційно напруженою, зростає відповідальність за навчальну успішність учнів при дефіциті матеріальних, фінансових та трудових ресурсів. Іноді особистісний потенціал педагога виявляється нижче або вище за потенціал, якого вимагає посадовий рівень. Недосконалість управлінської вертикалі та умов праці, у свою чергу, призводять до конфліктів, особистісних деформацій та до різного роду психосоматичних захворювань серед вчителів та учнів.

Важливим компонентом у структурі особистості педагога є професійно важливі якості. В. Шадриков під професійно важливими якостями розуміє індивідуальні якості суб'єкта діяльності, що впливають на ефективність діяльності й успішність їі засвоєння [15]. До професійно важливих якостей він відносить також і здібності. Домінантними якостями у професійно- 
педагогічній діяльності (Р. Мижериков, М. Срмоленко) є активність особистості, цілеспрямованість, урівноваженість, бажання працювати зі школярами, здатність не розгублюватися в екстремальних ситуаціях, чесність, справедливість, сучасність, педагогічний гуманізм, ерудиція, педагогічний такт, толерантність, дисциплінованість, педагогічний оптимізм [6]. Крім названого, слід додати такі якості, як вимогливість, відповідальність, комунікабельність.

Лідерські якості важливі не лише як засіб самоствердження особистості в студентські роки, але i для подальшої соціальної адаптації випускника педагогічного ВНЗ у жорстких, екстремальних ситуаціях сучасного життя. Лідерські якості сприяють конкурентоспроможності майбутнього вчителя в умовах життєдіяльності, що постійно змінюються. Джефф Сміт виявив основні характеристики ефективного лідера, з-поміж яких слід виокремити [11]:

- відповідність високим моральним стандартам;

- здатність створювати атмосферу ентузіазму та енергіі;

- підтримка членів команди за допомогою надання конструктивного зворотного зв'язку;

- справедливість;

- $\epsilon$ посередником у конфліктних ситуаціях;

- здатність вербального переконання;

- відкрита реакція на ідеї оточуючих.

На думку О. Кудряшової, «цінностями лідерства є навчання, натхнення i розвиток інших» [8]. Сутність лідерства полягає у прагненні і можливості здійснювати особистісний вплив на оточення, але й специфіка педагогічної професії полягає в тому ж. На жаль, вища педагогічна освіта ще не повною мірою зорієнтована на особистість майбутнього вчителя, формування i розвиток його лідерських якостей.

Поняття лідерства невід'ємно пов'язане з поняттям мотивації. Відомий американський науковець Ф. Котлер стверджує, що «мотивація - це процес стимулювання себе та інших до дій, який спрямований на досягнення індивідуальних та організаційних цілей» [7]. Етимологічно терміни «мотивація» та «емоція» походять від одного латинського дієслова movere, що означає «рухатися». Відомо, що так само, як потреби спонукають нас до дій, емоції керують нашими вчинками. Схематично сукупність необхідних у педагогічній діяльності компетенцій можна згрупувати у три блоки: індивідуальні навички, здібності вчителя та рівень його емоційного інтелекту [16] (рис. 1).

Емоція - це реакція, що відображається як почуття, яке мотивує, організує та спрямовує сприйняття, мислення та діяльність людини [5]. Вона мобілізує енергію, яка нині у більшості випадків призводить до скоєння людиною невиважених дій. Задачею емоційного інтелекту, перш за все, є формування в індивіда здатності усвідомлювати власні емоції та спрямовувати їх на подолання індивідуальних обмежень та міжособистісних конфліктів. Більше того, наявність емоційного інтелекту в педагога здатна змінити емоційну атмосферу в колективі та підняти мотивацію на якісно новий рівень. 


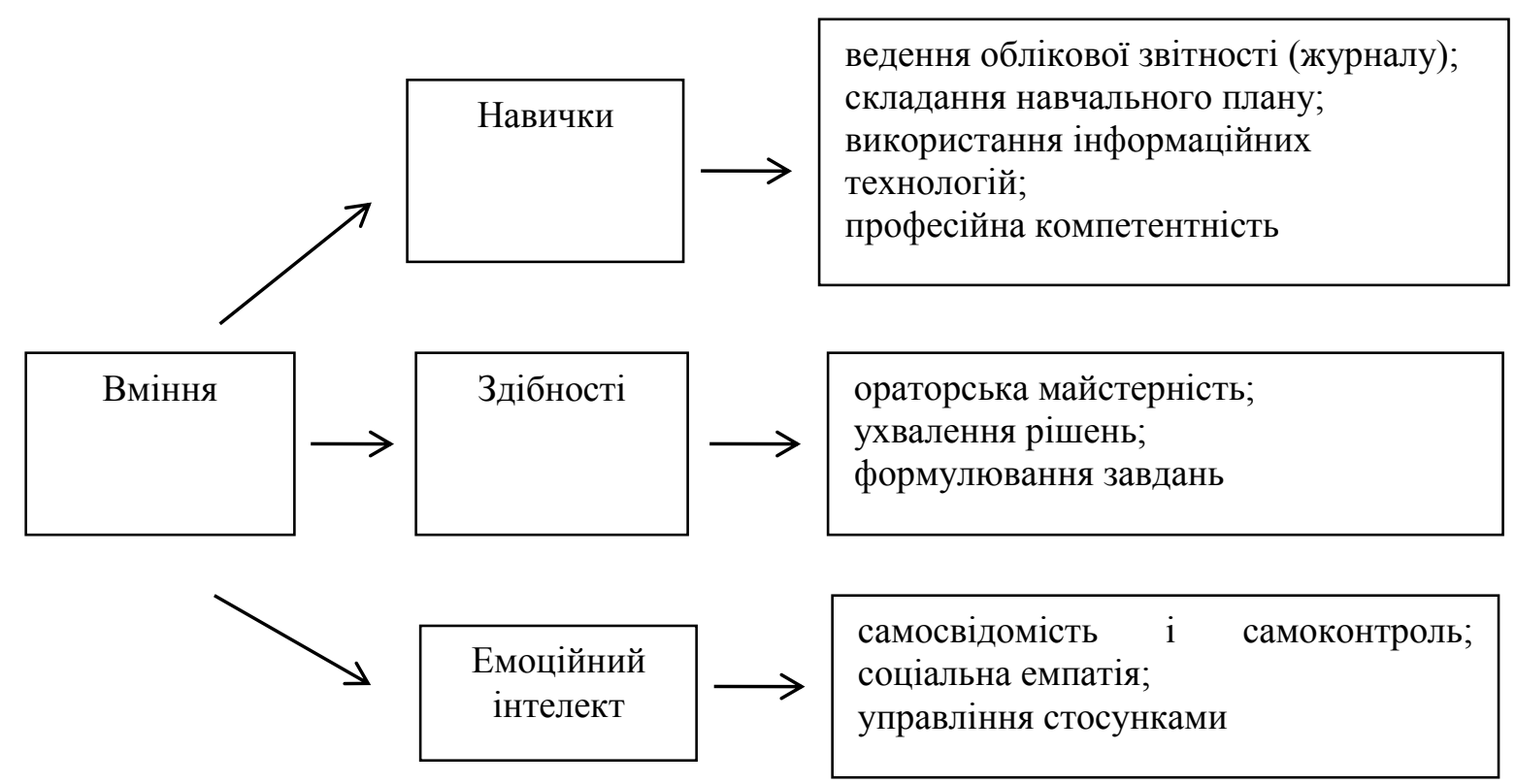

Рис. 1. Класифікаиія компетенцій, щуо необхідні для ефективної діяльності вчителів [7]

Згідно 3 Д. Гоулманом, емоційний інтелект - це «здатність людини пояснювати власні емоції та емоції оточуючих з тим, щоб використовувати отриману інформацію для реалізації власних цілей» [1]. Р. Бар-Он по-іншому визначає емоційний інтелект: «безліч некогнітивних здібностей і навичок, що впливають на здатність успішно справлятися з вимогами і тиском оточуючих».

Гольман установив, що в основу емоційного інтелекту покладено упевненість у собі, знання своїх власних здібностей і обмежень, а також тверде розуміння причин і ситуацій, що викликають ту або ту емоцію в собі та інших. Маючи такі здібності, педагог зможе управляти своїми емоціями та поведінкою на якісно вищому рівні, краще розуміти і будувати стосунки 3 іншими людьми [3].

Яким чином людина сприймає довкілля? Інформація із зовнішнього середовища через сенсорні канали потрапляє до лімбічної системи, що відповідає за емоційний складник, потрапляє до мигдалеподібного тіла та лише після цього за допомогою нейронних систем переходить до префронтальної зони, яка $\epsilon$ виконавчим органом мозку. У повсякденному житті мозок здатен блокувати емоційну реакцію, але за умов критичної ситуації лімбічна система підкоряє собі всю мозкову діяльність [1].

Деякі науковці та практики, що використовують емоційний інтелект у своїй діяльності, стверджують, що поняття емоційного інтелекту та емоційної компетентності $є$ синонімами [1, с. 14]. Певний рівень емоційного інтелекту потрібен для формування конкретних компетенцій, пов'язаних 3 емоціями. Наприклад, здатність чітко розпізнати, що відчуває інша людина, дає можливість розвинути такі компетенції, як здатність впливати на інших людей і надихати їх. Так само, людям, які краще спроможні управляти своїми емоціями, легше розвивати такі компетенції, як ініціативність i здатність працювати в стресовій ситуації. 
Під компетенціями переважно розуміються здібності, що відбивають стандарти поведінки, тобто знання, уміння, навички, індивідуально-особистісні характеристики, необхідні для якісного виконання роботи. Компетентність це динамічна характеристика особи, не наявність якостей, а здатність їх ефективно, 3 максимальною віддачею, застосовувати. Деякі дослідники (С. Уїддет, С. Холліфорд) виокремлюють кластери компетенцій, тобто набір тісно пов'язаних компетенцій. До кластерів відносяться: робота з людьми, робота 3 інформацією, розвиток бізнесу тощо. Зупинимося на деяких компетенціях 3 кластера «робота з людьми», які є складовниками емоційного інтелекту.

Найбільш важливими складовими емоційного інтелекту ми вважаємо самосвідомість, саморегулювання та соціальні навички. Між ними існує прямий взаємозв'язок, оскільки регулювання не можливе без усвідомлення, а соціальні навички у суспільстві будуються на основі індивідуальних характеристик. Нижче наведено рисунок, який розкриває взаємозалежність складовників емоційного інтелекту (рис. 2).

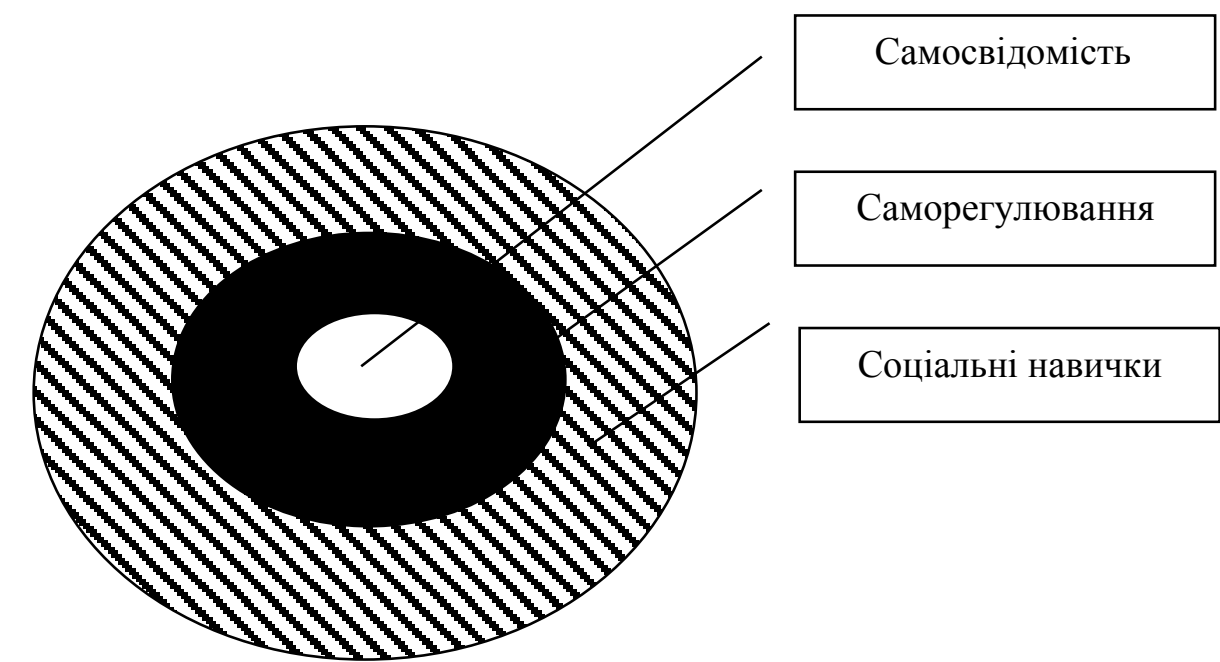

Рис. 2. Взаємозалежність складників емоиійного інтелекту [1]

1. Самосвідомість. Ї̈̈ визначають як розуміння характеру власних емоцій разом 3 усвідомленням власних сильних та слабких якостей, цінностей та мотивів [2]. У більш широкому розумінні цього терміна можна сказати, що емоційна самосвідомість означає здатність людини аналізувати, які думки, рішення та дії зумовили чи зумовлюють появу конструктивних чи деструктивних емоцій. До складу самосвідомості входять: емоційна самосвідомість, інтуїція, самоаналіз та впевненість у власних силах.

2. Саморегулювання - це складник емоційного інтелекту, який не дозволяє емоціям керувати життєдіяльністю людини. Зважаючи на відсутність у психологічній літературі єдності думок у визначенні поняття саморегуляції, у найзагальнішому вигляді під психічним самоврядуванням (саморегулюванням) прийнято вважати свідомі дії людини на властиві йому психічні явища (процеси, стани і властивості), а також виконувану ним 
діяльність i власну поведінку задля підтримки або зміни характеру їх перебігу (функціонування) [9].

Оскільки емоції мають властивість передаватися іншим, особливо від керівника до підлеглого (від учителя до учня), першочерговим завданням лідера $\epsilon$ контроль власних емоцій. Складуиками саморегулювання $\epsilon$ самомотивація, керування емоціями, відкритість та здатність адаптуватися.

3. Соціальні навички. Якщо самоусвідомлення та саморегулювання спрямовані на внутрішнє середовище людини, соціальні навички відображають, наскільки в індивіда розвинена здатність функціонувати в зовнішньому середовищі під час взаємодії 3 оточуючими. Складовниками соціальних навичок є емпатія, ділова обізнаність, «вплив» та командна робота [1].

Людина, як відомо, характеризується наявністю відкритої лімбічної системи. Системи закритого типу, такі, як кровоносна - саморегулюються: те, що відбувається у кровоносних системах оточуючих, не впливає на наш кровообіг. На відміну від кровообігу, емоційний стан, як правило, залежить від навколишнього середовища.

Відкритість системи науковці характеризують як «міжособову лімбічну саморегуляцію», за допомогою якої людина передає сигнали, які здатні змінити рівень гормонів, функції серцево-судинної системи, ритм сну і навіть характер імунного захисту іншої людини [7].

На початку розмови організми співрозмовників функціонують незалежно один від одного. Але на кінець п'ятнадцятихвилинної розмови фізіологічні характеристики зближуються. Це явище отримало назву дзеркального відображення. Такого роду взаємопроникнення виявляється особливо на етапі посилення конфлікту, коли негативні емоції взаємно відбиваються та накопичуються.

У 2010 році Л. Дакуша та Л. Купреєва провели дослідження, яке грунтувалося на гіпотезі, що емоційний інтелект особистості пов'язаний з іiі моральністю [4]. У дослідженні взяли участь старшокласники 10-х та 11-х класів у кількості 36 осіб. У дослідженні використовувалася авторська методика Л. Попова, А. Кашина [10], метою якої є оцінювання двох альтернативних характеристик особистості за функціями якості добра та зла («ДОБРО-ЗЛО»). Результати кореляційного аналізу свідчать, що показники емоційного інтелекту старшокласників тісно пов’язані зі шкалою «Добро». Найбільший позитивний зв'язок було виявлено між комунікативним емоційним інтелектом та шкалою «Добро».

Кореляційний аналіз дослідження також виявив відсутність статистично вагомого зв'язку між емоційним інтелектом та шкалою «Зло». Сильний позитивний зв'язок досліджувався між загальним емоційним інтелектом та шкалою «Людяність», що відображає рівень морального розвитку людини.

Результати проведеного Л. Дакушею та Л. Купреєвою дослідження, підтверджують наявність зв'язку між емоційним інтелектом та моральністю старшокласників, що, у свою чергу, дозволяє говорити про необхідність впливу на емоційний інтелект підлітків з боку педагогів задля формування 
етично та морально розвиненої особистості.

За умови умілого використання, кожна емоція може бути позитивним внеском у діяльність викладача. Розглянемо стилі емоційного лідерства (рис. 3):

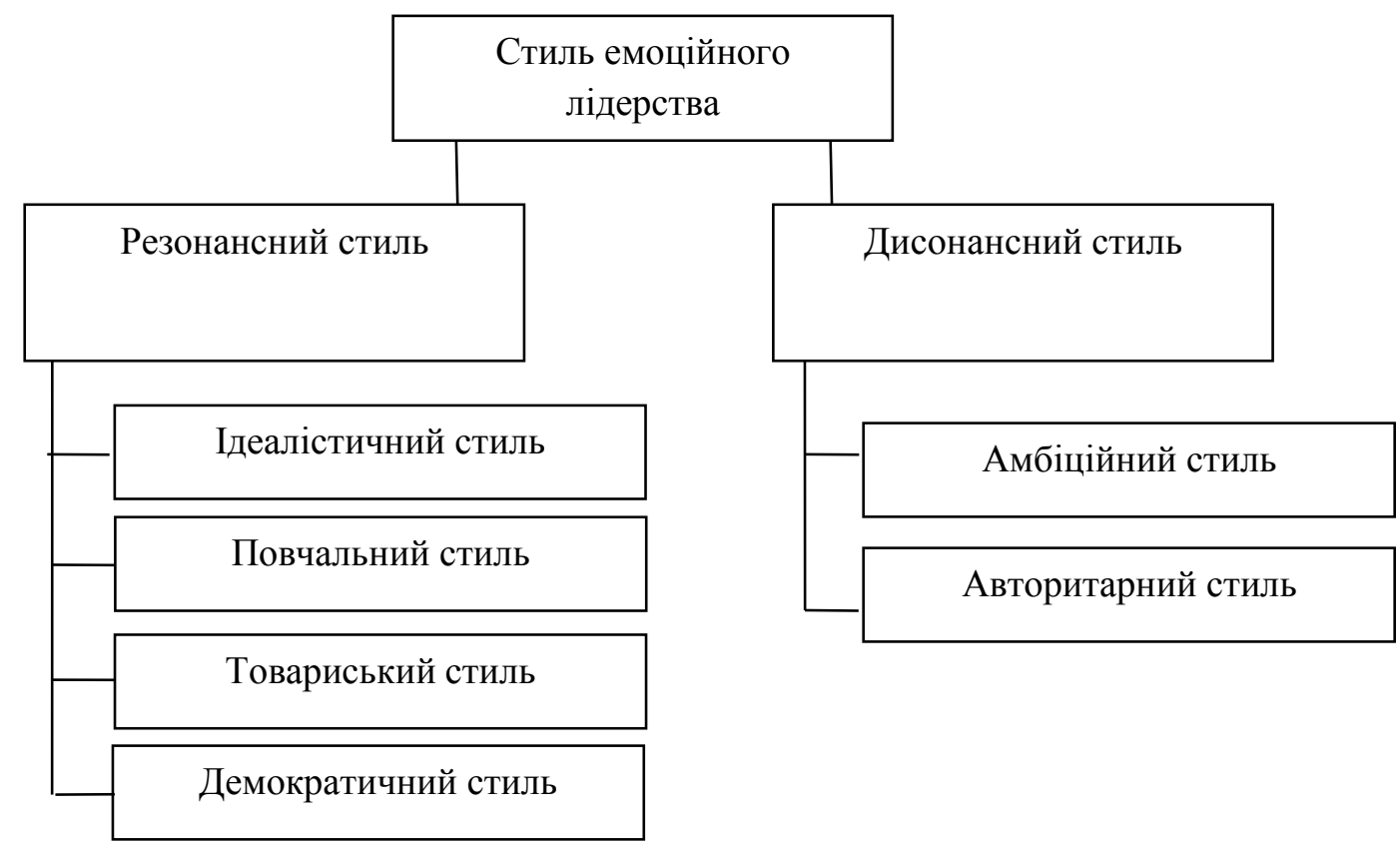

Рис. 3. Стилі емоиійного лідерства [1]

Коли лідери пробуджують в оточуючих позитивні емоції, вони апелюють до найкращих якостей колективу. Цей ефект у психології має назву резонанс. I навпаки, коли керівник викликає негативну реакцію, утворюється дисонанс, який негативно впливає на основи, на яких тримається емоційний взаємозв'язок між учителем та учнями (таб. 1).

Найбільш ефективні педагоги не лише механічно обирають функціональні стилі [12]. Вони уважно вивчають учнів, намагаючись зрозуміти, який стиль найдоцільніше використовувати у тій чи іншій ситуації. Головним у процесі професійного володіння компетенціями емоційного лідера $\epsilon$ закріплення базових навичок емоційного інтелекту та більш глибоке розуміння емоційних характеристик колективу.

На основі проведеного дослідження, уважаємо доцільним рекомендувати ввести до процесу підготовки педагогів курси, які сприятимуть розвитку емоційних компетенцій. Метою курсів є виведення процесу навчання на якісно новий рівень шляхом формування розуміння між педагогом та колективом, розвитку сприятливої для навчання атмосфери. За умови більш детального вивчення компетенцій емоційного інтелекту існує можливість впливу не лише на морально-етичне обличчя підлітків, а й на самосвідомість молоді, розуміння необхідності глибокого вивчення навчального матеріалу. 
Таблиия 1

Характеристика переваг та недоліків резонансних та дисонансних стилів лідерства

\begin{tabular}{|c|c|c|c|}
\hline Назва & $\begin{array}{l}\text { Необхідні для } \\
\text { використання } \\
\text { стилю якості }\end{array}$ & Недоліки & Переваги \\
\hline $\begin{array}{l}\text { Ідеалістичний } \\
\text { стиль }\end{array}$ & $\begin{array}{l}\text { Натхнення } \\
\text { Емпатія }\end{array}$ & $\begin{array}{l}\text { Не рекомендується для роботи } \\
3 \text { аудиторією, емоційний стан } \\
\text { якої знаходиться під загрозою }\end{array}$ & $\begin{array}{l}\text { Найефективніший за } \\
\text { умов реорганізації }\end{array}$ \\
\hline $\begin{array}{l}\text { Повчальний } \\
\text { стиль }\end{array}$ & $\begin{array}{l}\text { Коучинг } \\
\text { Керування } \\
\text { емоціями } \\
\text { Емпатія }\end{array}$ & $\begin{array}{l}\text { Може сприйматися як вияв } \\
\text { надмірного контролю }\end{array}$ & $\begin{array}{l}\text { Доцільний за умов } \\
\text { високої мотивації } \\
\text { колективу }\end{array}$ \\
\hline $\begin{array}{l}\text { Товариський } \\
\text { стиль }\end{array}$ & $\begin{array}{l}\text { Командна робота } \\
\text { Співчуття }\end{array}$ & \begin{tabular}{|lr} 
Нехтування & основними \\
цінностями & навчального \\
закладу & \\
\end{tabular} & $\begin{array}{l}\text { Створює сильний } \\
\text { командний дух }\end{array}$ \\
\hline $\begin{array}{l}\text { Демократичний } \\
\text { Стиль }\end{array}$ & $\begin{array}{l}\text { Сприяння змінам } \\
\text { Відкритість } \\
\text { Керування } \\
\text { емоціями }\end{array}$ & $\begin{array}{l}\text { Перетворення діяльності на } \\
\text { нескінченні наради }\end{array}$ & 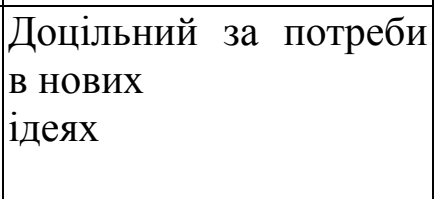 \\
\hline $\begin{array}{l}\text { Амбіційний } \\
\text { стиль }\end{array}$ & - & $\begin{array}{l}\text { Утворення } \\
\text { нестабільності в колективі }\end{array}$ & $\begin{array}{l}\text { Ефективний за умов } \\
\text { роботи із } \\
\text { зорієнтованими на } \\
\text { високі академічні } \\
\text { досягнення учнями } \\
\end{array}$ \\
\hline $\begin{array}{l}\text { Авторитарний } \\
\text { стиль }\end{array}$ & 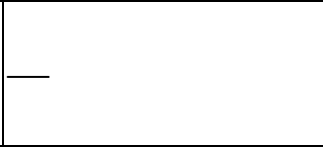 & $\begin{array}{l}\text { Фокусування уваги лише на } \\
\text { недоліках }\end{array}$ & $\begin{array}{|lr|}\text { Якщо } & \text { необхідно } \\
\text { ліквідувати } \\
\text { порядки }\end{array}$ \\
\hline
\end{tabular}

\section{Література}

1. Гоулман Д. Эмоциональное лидерство / Д. Гоулман, Р. Бояцис, Э. Макки. - М. : Альпина Бизнес Букс, 2008. - 301с.

2. Далай-Лама. Мудрость Востока и Запада. Психология равновесия / Далай-Лама, П. Экман. - СПб. : Питер, 2011. - 304c.

3. Данилова О. В. Составляющие лидера установлены. Эффективный менеджмент и эмоциональный интеллект / О. В. Данилова / [Електронний ресурс]. - Режим доступу : http://www.effecton.ru/347.html. - Заголовок з екрану.

4. Дакуша Л. М. Развитие эмоционального интеллекта старшеклассников / Л. М. Дакуша, Л. Л. Купреева // Вестник ГрГУ. Сер. 3. Филология. Педагогика. Психология. - 2010. - № 3. - С. 133-137.

5. Изард К. Е. Психология эмоций: [монография] / К. Е. Изард. - СПб. : Питер, 2011. $-461 \mathrm{c}$.

6. Компетентность в образовании: [библиограф. пособие] / ред. Л. К. Кириловских. - Камышлов, 2009. - 12 с.

7. Котлер Ф. Основы маркетинга / Ф. Котлер, В. Вонг, Д. Сондерс, Г. Амстронг. М. : «И. Д. Вильямс», 2008. -450 с.

8. Кудряшова Е. В. Лидер и лидерство: Исслед. лидерства в соврем. зап. обществ.полит. мысли / Е. В. Кудряшова. - Архангельск : Изд-во Помор. междунар. пед. ун-та им. М. В. Ломоносова, 1996. -252 с.

9. Никифоров Г. С. Психология здоровья : [учеб. пособ.] / Г. С. Никифоров. - СПб. : Речь, 2002. - 256 с. 
10. Попов Л. М. Добро и зло в этической психологии личности / Л. М. Попов, О. Ю. Голубева, П. Н. Устин. - М. : Изд-во «Институт психологии РАН», 2008. - 240 с.

11. Смит Д. Лидерство в сфере профессиональных услуг / Д. Смит; [пер. с англ.] Днепропетровск: Баланс Бизнес Букс, 2005. - 288c.

12. Сухомлинский В. А. Сердце отдаю детям / В. А. Сухомлинский. - К. : Рад. школа, 1985. - $557 \mathrm{c.}$

13. Трифонов Е. В. Пневмапсихосоматология человека. Русско-англо-русская энциклопедия [Електронний ресурс] / Е. В. Трифонов. - Режим доступу : http://www.tryphonov.ru - Заголовок з екрану.

14. Шабанов С. Эмоциональная компетентность, эмоциональный интеллект [Електронний ресурс] / С. Шабанов, А. Алешина. - Режим доступу : http://www.eqspb.ru/eq.htm - Заголовок з екрану.

15. Шадриков В. Д. Психология деятельности и способности человека [Електронний ресурс] / В. Д. Шадриков. - Режим доступу:http://psylib.net/vd-shadrikovpsixologiya-deyatelnosti-i-sposobnosti-cheloveka/ - Заголовок з екрану.

16. Эмоциональный интеллект команды [Електронний ресурс]. - Режим доступу: http://www.zarabotu.ru - Мова poc.

Стаття надійшла до редакції 12.05.2012 p.

УДК 378.1

\author{
А. В. Желан, \\ кандидат пед. наук, доцент, \\ Інститут педагогічної освіти \\ МНУ ім. В. О. Сухомлинського
}

\title{
ІНТЕГРАЦЯ ПЕДАГОГІЧНОЇ УНІВЕРСИТЕТСЬКОЇ ОСВІТИ УКРАЇНИ ДО ЗАГАЛЬНОЕВРОПЕЙСЬКОГО ОСВІТНЬОГО ПРОСТОРУ
}

Желан А. В. Інтеграчія педагогічної університетської освіти Украӥни до загальноєвропейського освітнього простору.

У статті розглянуто сучасні тендениії інтеграчії вищої педагогічної освіти України до загальноєвропейського освітнього простору, зміст університетської педагогічної освіти, формування системи підготовки вчителів, навчальний процес у ВНЗ.

Ключові слова: вища педагогічна освіта, університети, навчальний проиес, педагогічна практика, освітній простір, інтеграиія.

Желан А. В. Интеграция педагогического университетского образования Украины в общеевропейский образовательный простор.

В статье рассматриваются современные тенденции интеграции выстего педагогического образования Украины, содержание университетского педагогического образования, формирование системы подготовки учителей, учебный процесс в вузах.

Ключевые слова: высшее педагогическое образование, университеты, учебный процесс, педагогическая практика, образовательное пространство, интеграиия.

Dgelan A. Integration of university education teacher of Ukraine into the European educational space.

The article deals with the current trends of integration of higher pedagogical education in Ukraine, the content of university teacher training, the creation of a system of teacher training, the learning process in higher educational establishments.

Key words: higher pedagogical education, universities, learning process, vocational practice, educational space, integration.

Актуальність проблеми. У зв'язку з приєднанням національної вищої школи до європейського освітнього простору проблема визначення іiі компонентів i ïx конкретного структурно-змістового наповнення посилила 